\title{
Increased bone mass in adult prostacyclin-deficient mice
}

\author{
Chalida Nakalekha ${ }^{1,2,3}$, Chieko Yokoyama ${ }^{1,4}$, Hiroyuki Miura ${ }^{2}$, Neil Alles ${ }^{3,5}$, Kazuhiro Aoki ${ }^{3,5}$, \\ Keiichi Ohya ${ }^{5}$ and Ikuo Morita ${ }^{1,3}$ \\ Departments of ${ }^{1}$ Cellular Physiological Chemistry and ${ }^{2}$ Fixed Prosthodontics, Graduate School, ${ }^{3}$ International Research Center for Molecular Science in Tooth \\ and Bone Diseases (Global COE program), Tokyo Medical and Dental University, 1-5-45 Yushima, Bunkyo-ku, Tokyo 113-8549, Japan \\ ${ }^{4}$ Institute of Cellular and System Medicine, National Health Research Institutes, Miaoli 35053, Taiwan, ROC \\ ${ }^{5}$ Department of Hard Tissue Engineering (Pharmacology), Graduate School, Tokyo Medical and Dental University, 1-5-45 Yushima, Bunkyo-ku, Tokyo 113-8549, \\ Japan \\ (Correspondence should be addressed to I Morita; Email: morita.cell@tmd.ac.jp)
}

\begin{abstract}
Prostaglandins (PGs) are key regulatory factors that affect bone metabolism. Prostaglandin $\mathrm{E}_{2}\left(\mathrm{PGE}_{2}\right)$ regulates bone resorption and bone formation. Prostacyclin $\left(\mathrm{PGI}_{2}\right)$ is one of the major products derived from arachidonic acid by the action of cyclooxygenase and $\mathrm{PGI}_{2}$ synthase (PGIS). Unlike $\mathrm{PGE}_{2}$, there are few reports about the role of $\mathrm{PGI}_{2}$ in bone regulation. Therefore, we investigated the potential effect of $\mathrm{PGI}_{2}$ on bone metabolism. We used PGIS knockout $\left(\mathrm{PGIS}^{-\prime-}\right)$, PGIS heterozygous $\left(\mathrm{PGIS}^{+/-}\right.$), and wild-type mice to investigate the role of $\mathrm{PGI}_{2}$. Notably, $\mathrm{PGIS}^{-1-}$ mice gradually displayed an increase in trabecular bone mass in adolescence. Adult PGIS ${ }^{-1-}$ mice showed an increase in trabecular bone volume/tissue volume. Histomorphometric analysis showed that PGIS $^{-1-}$ mice displayed increases in
\end{abstract}

both bone formation and bone resorption parameters. Levels of serum osteocalcin and C-telopeptides were increased in adult PGIS $^{-1-}$ mice. Furthermore, the increased bone mass patterns were rescued in $\mathrm{PGIS}^{-} /^{\mathrm{tg}}$ mice. In conclusion, adult PGIS $^{-/-}$mice displayed an overall increase in the levels of both bone formation and bone resorption parameters, which suggests that $\mathrm{PGI}_{2}$ deficiency accelerates high bone turnover activity with a greater increase in bone mass in aging. These results indicated that $\mathrm{PGI}_{2}$ may contribute to the maintenance of normal bone mass and micro-architecture in mice in age-dependent manner. Our findings demonstrate for the first time that $\mathrm{PGI}_{2}$ is involved in bone metabolism in vivo.

Journal of Endocrinology (2010) 204, 125-133

\section{Introduction}

Prostaglandins (PGs) are one of the regulatory factors that affect bone metabolism (Raisz 1995, 1999, Harada \& Rodan 2003). They are produced by the sequential oxygenation of arachidonic acid by cyclooxygenases (COXs) and terminal PG synthases (Simmons et al. 2004). The metabolites of COXs are involved in skeletal development. $\mathrm{PGE}_{2}$ regulates bone remodeling by mediating osteoblast differentiation (Yoshida et al. 2002, Arikawa et al. 2004) and regulates bone resorption by increasing cAMP levels through $\mathrm{EP}_{2}$ and $\mathrm{EP}_{4}$ receptor activation (Li et al. 2000, Miyaura et al. 2000, Yoshida et al. 2002, Sugimoto \& Narumiya 2007). Prostacyclin $\left(\mathrm{PGI}_{2}\right)$, a product converted by COXs and $\mathrm{PGI}_{2}$ synthase (PGIS), also up-regulates cAMP levels through the activation of a $\mathrm{PGI}_{2}$ receptor (IP; Namba et al. 1994). Resident bone cells; osteoblasts and osteocytes, can produce both $\mathrm{PGE}_{2}$ and $\mathrm{PGI}_{2}$ under mechanical loading (Rawlinson et al. 1991, 2000). Osteoblasts also produce $\mathrm{PGI}_{2}$ in response to growth factors such as vascular endothelial growth factor (Clarkin et al. 2008).
Genetic manipulation in mice has been a powerful tool for a better understanding of mammalian physiology. COX-2 gene deletion in mice induced a negative effect on bone formation by reducing osteoblastogenesis and delaying bone healing (Zhang et al. 2002, Naik et al. 2009), while skeletal abnormalities have not yet been reported in membraneassociated PGE synthase 1 null mice (Uematsu et al. 2002, Kamei et al. 2004).

Bone regulation during development processes has been widely studied (Harada \& Rodan 2003). In contrast, information about controlling bone remodeling and maintaining bone mass in adults, which could contribute to therapeutic applications, remains limited. Although the critical role of $\mathrm{PGE}_{2}$ in bone has been widely demonstrated, the role of $\mathrm{PGI}_{2}$ is poorly understood. In a recent paper, it has been demonstrated that the injected iloprost, a stable $\mathrm{PGI}_{2}$ analog, stimulated calvarial bone formation in postnatal rats (Tuncbilek et al. 2008). Hence, the focus of the present study was to investigate the potential roles of $\mathrm{PGI}_{2}$ in bone metabolism. 
In the present study, we investigated skeletal abnormalities in both young and adult $\mathrm{PGI}_{2}$-deficient mice. Bone abnormalities were assessed by radiography, histomorphometric analysis, and the measurement of biological markers. We found an increase in the bone mass of adult $\mathrm{PGI}_{2}$-deficient mice. Based on our results, the high bone mass phenotype in aged PGIS-null mice was a result from net favor of bone formation and mineralization. This phenotype was rescued in the offspring of PGIS-knockout mice crossbred with PGIStransgenic mice. This evidence suggests that $\mathrm{PGI}_{2}$ is involved in bone metabolism and contributes to the lifelong maintenance of normal bone mass and micro-architecture in mice.

\section{Materials and Methods}

\section{Animals}

Female PGIS-null mice in a C57BL/6 strain (Yokoyama et al. 2002) were used in our study. PGIS ${ }^{+/-}$animals have no abnormal phenotype. PGIS-transgenic mice were generated in a C57BL/6 strain by the microinjection method. Mouse PGIS cDNA was inserted into the multicloning site of the modified pCI-neo mammalian expression vector (Promega), in which the CMV immediate early enhancer/promoter was replaced with the CMV early enhancer/chicken $\beta$-actin (CAG) promoter. The linearized plasmid was microinjected in fertilized eggs from C57BL/6J mice (CLEA Japan Inc., Osaka, Japan). The PGIS ${ }^{\text {tg/tg }}$ mice were crossbred with $\mathrm{PGIS}^{-/-}$mice to generate $\mathrm{PGIS}^{-/-} / \mathrm{PGIS}^{\mathrm{tg} / \mathrm{tg}}\left(\mathrm{PGIS}^{-} / \mathrm{tg}^{\mathrm{g}}\right)$ littermates. PGIS gene expression levels in the $\mathrm{PGIS}^{-} /{ }^{\mathrm{tg}}$ mice were confirmed by quantitative real-time PCR by using the DyNAmo probe qPCR kit (Finnzymes, Espoo, Finland). Mice were allowed food (CE-2; CLEA Japan Inc.) and distilled water ad libitum. Mice were maintained in a $12 \mathrm{~h}$ light:12 h darkness cycle. The experimental procedures were reviewed and approved by the Animal Care and Use Committee of Tokyo Medical and Dental University.

\section{Radiographic assessment of bone}

Peripheral quantitative computed tomography analysis For the longitudinal assessment of bone, 5- to 34-week-old mice were kept alive during the bone density measurement by peripheral quantitative computed tomography (pQCT) (XCT Research SA+; Stratec Medizintechnik GmbH, Pforzheim, Germany) (Aoki et al. 2006, Alles et al. 2009). To conduct high-resolution scanning mode $\mathrm{pQCT}$, mice were anesthetized with injections of medetomidine hydrochloride $(0.5 \mathrm{mg} / \mathrm{kg}$; Meijiseika, Tokyo, Japan) and ketamine hydrochloride $(50 \mathrm{mg} / \mathrm{kg}$; Sankyo, Tokyo, Japan; Saito et al. 2007).

Soft X-ray, dual X-ray absorptiometry and microfocal-computed tomography analysis The mice were killed by using ether anesthesia. Their hind limbs (tibias and femurs) were harvested. Muscles and soft tissue were roughly removed from the bones, and then the bones were fixed in phosphate-buffered glutaraldehyde $(2 \cdot 5 \%)$-formalin (4\%) fixative ( $\mathrm{pH} 7 \cdot 4)$ for 2 days. Then, the samples were rinsed and kept in PBS for 2 days and water for 1 day. Afterward, the prepared bone samples were used for the soft X-ray radiographic analysis (SRO-M50; Sofron, Tokyo, Japan).

Trabecular and cortical regions of long bones were assessed by conducting a longitudinal study with dual X-ray absorptiometry (DXA; DCS-600R; Aloka, Tokyo, Japan; Saito et al. 2007, Hussain Mian et al. 2008, Alles et al. 2009) and determining the trabecular bone volume/tissue volume (\%) (BV/TV) by microfocal CT (micro-CT; SMX-90CT, Shimadzu, Kyoto, Japan) respectively. Trabecular bone in secondary spongiosa was measured at a $450-500 \mu \mathrm{m}$ distance from the growth plate of the tibia to avoid primary spongiosa.

\section{Histological assessment of bone}

Mice received s.c. injections of demeclocycline hydrochloride $(8 \mathrm{mg} / \mathrm{kg}$ of body weight; Sigma) and calcein $(10 \mathrm{mg} / \mathrm{kg}$ of body weight; Sigma) at 10 days and 3 days prior to killing respectively. After micro-CT analysis, the bone specimens were embedded as undecalcified sections in mixtures of methyl methacrylate and 2-hydroxyethylmethacrylate resins, as described previously (Saito et al. 2007). Polymerization was performed at $4{ }^{\circ} \mathrm{C}$. Standard sections $(3 \mu \mathrm{m}$ thick) were prepared with a Reichert-Jung microtome 2050 Supercut (Cambridge Instrument, Heidelberger, Switzerland). Undecalcified sections were stained with tartrate-resistant acid phosphatase (TRAP) and counterstained with toluidine blue. Some sections were stained with Von Kossa for visualizing mineralization. Standard histomorphometric analysis of the tibial metaphysis was performed by using an image analyzing system (KS400, Carl Zeiss, Jena, Germany), as described elsewhere (Parfitt et al. 1987, Aoki et al. 2006).
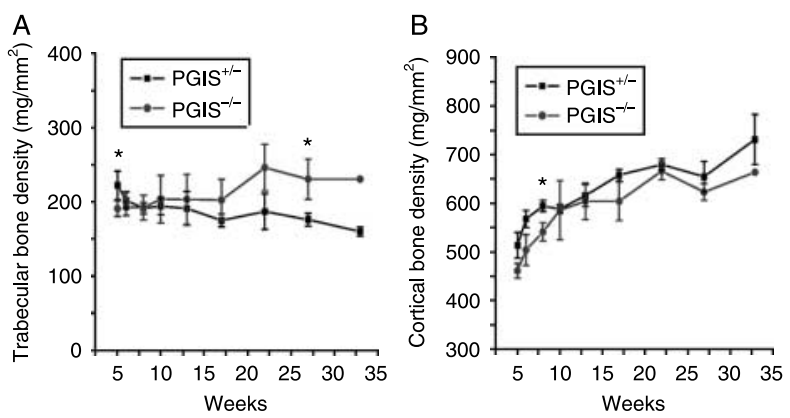

Figure $1 \mathrm{PGl}_{2}$-deficient mice displayed skeletal changes in a timecourse analysis. A longitudinal assessment of the bone density of mouse tibia was performed by pQCT. Trabecular bone density (A) and cortical bone density (B) in $\mathrm{PGIS}^{-1-}$ mice tibia from 5- to 33-week-old anesthetized mice were measured. $\mathrm{PGIS}^{+/-}$mice were used as a control. Values are mean \pm s.D., $n=3$, except 33-week-old PGIS ${ }^{-1-}$ mice, $n=2,{ }^{*} P<0 \cdot 05$. 
Measurement of bone biological markers

After blood samples were collected, serum osteocalcin levels were measured by using a Mouse osteocalcin EIA kit (Biomedical Technologies Inc., Stoughton, MA, USA; Tomomatsu et al. 2009). The quantity of C-terminal telopeptides (CTX), which are generated by osteoclasts as a degradation product of type I collagen, was measured by RatLaps EIA (Immunodiagnostic system, Boldon, UK; Garnero et al. 2003).

\section{Statistical analyses}

Statistical analysis was performed by using the Student's $t$-test and one-way ANOVA. When a significant $F$ ratio was identified, groups were compared by using Tukey's honestly significant differences (HSD) protected least-significant difference post hoc test.

\section{Results}

Skeletal phenotypic change was detected in PGIS ${ }^{-1-}$ mice

PGIS $^{-/-}$mice were born at the expected Mendelian ratio with grossly normal bone shape and size. Body weights of PGIS $^{-/-}$mice were similar to those of $\mathrm{PGIS}^{+\prime-}$ and wildtype (WT) littermates. PGIS ${ }^{+/}$mice showed no obvious phenotype change. We examined the change in bone content in 5-week-old anesthetized PGIS-null mice by pQCT measurement, and the $\mathrm{PGIS}^{-/-}$mice showed a significant decrease in trabecular bone density. The pQCT measurement was repeated periodically. Over time, $\mathrm{PGIS}^{-/-}$mice developed an increase in trabecular bone density that became significantly different as compared to $\mathrm{PGIS}^{+/-}$ littermates (by week 27; Fig. 1A). Cortical bone density in PGIS $^{-/-}$mice at the later period of life was not significantly different (Fig. 1B).

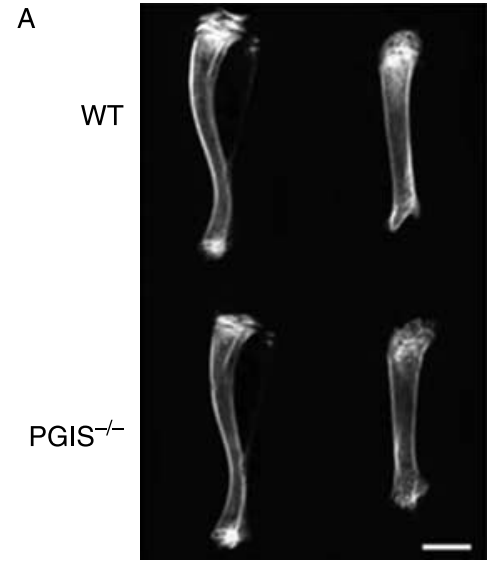

B

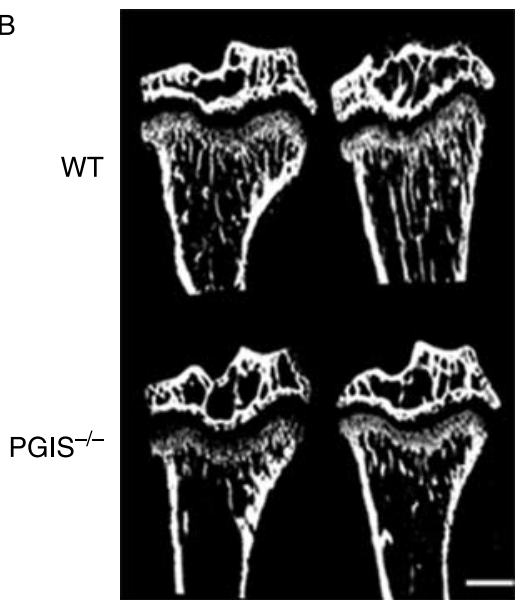

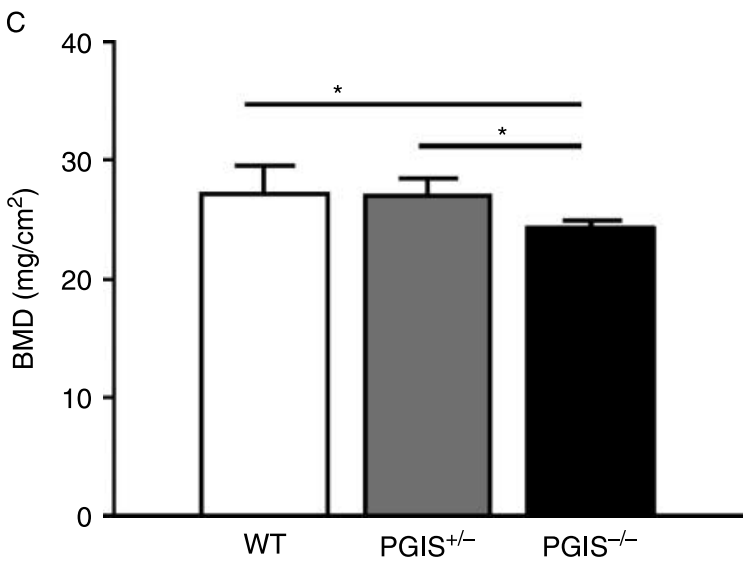

D

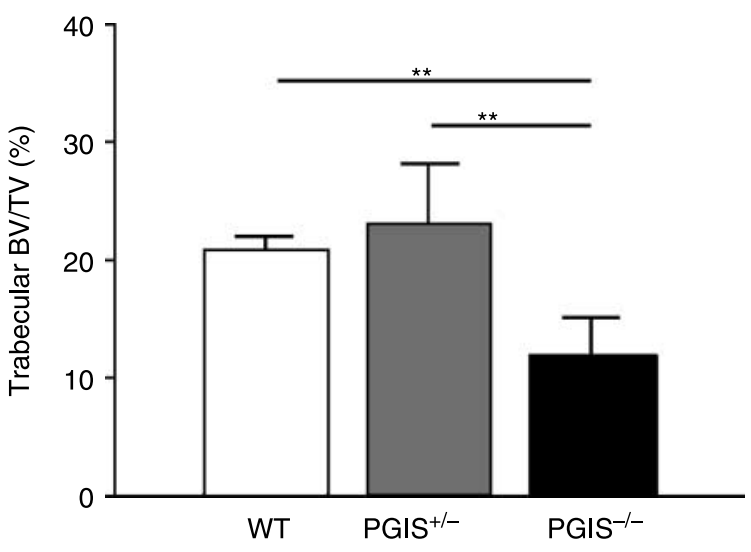

Figure 2 Decreased bone mass in 5-week-old $\mathrm{PGIS}^{-1-}$ mice. Five-week-old $\mathrm{PGIS}^{-1-}$ mice had lower trabecular bone density, as determined by soft X-ray (A) (scale bar $=5 \mathrm{~mm}$ ) and micro-CT analysis of distal tibia metaphysis (B) (scale bar $=1 \mathrm{~mm}$ ). From DXA results, the tibial bone mineral density $\left(B M D, \mathrm{mg} / \mathrm{cm}^{2}\right)$ in $\mathrm{PGIS}^{-1-}$ mice was lower than in wild-type (WT) and PGIS ${ }^{+/-}$mice (C). Micro-CT analysis demonstrated a lower trabecular bone volume/tissue volume (BV/TV, \%) in $\mathrm{PGIS}^{-1-}$ mice (D). Values are mean \pm s.D., $n=7$, 4 , and 6 respectively, $* P<0 \cdot 05, * * P<0 \cdot 01$. 

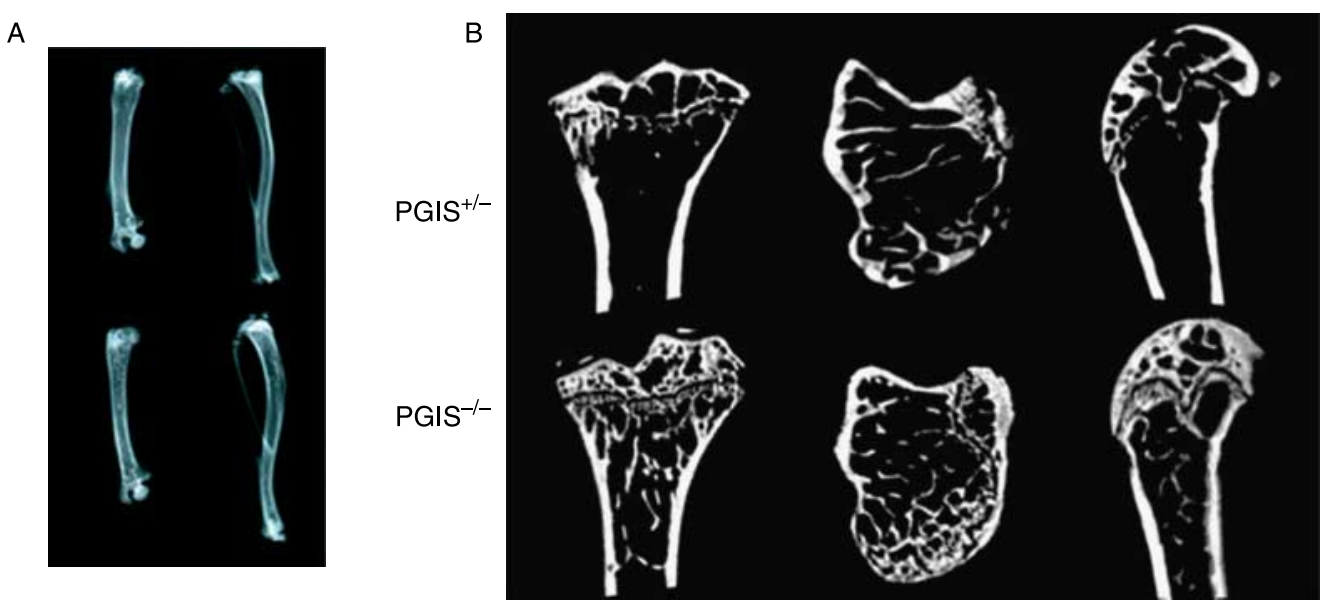

C
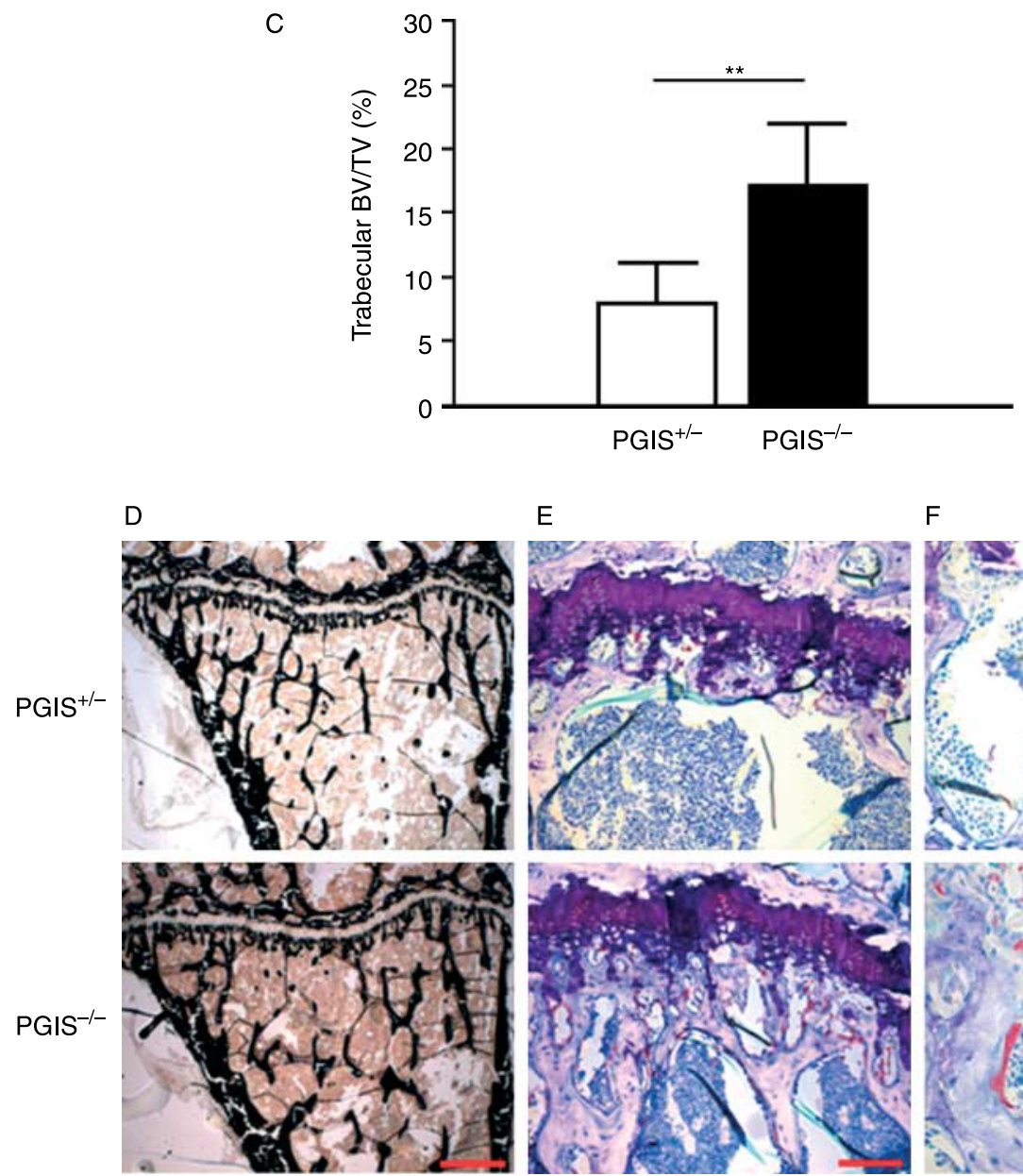

E

$\mathrm{F}$
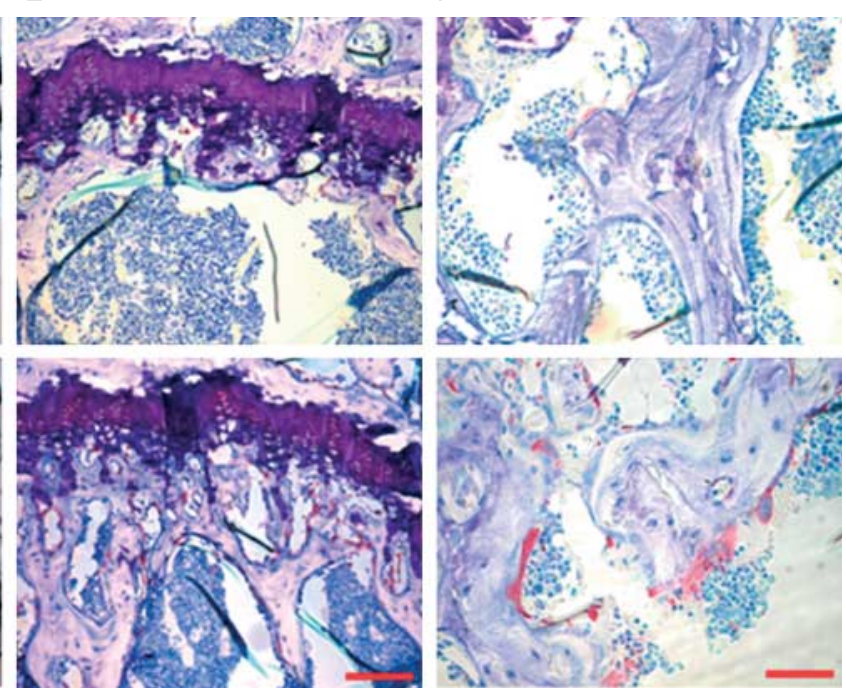

Figure 3 Trabecular bone was increased in adult $\mathrm{PGIS}^{-1-}$ mice. The 34-week-old PGIS ${ }^{-1-}$ mice showed an increased bone mass phenotype at the distal metaphysis of the tibia and femur, as determined by soft tissue X-ray (A) and micro-CT analysis (B) respectively. Trabecular BV/TV (\%) of the tibia metaphysis in $\mathrm{PGIS}^{-1-}$ mice was increased (C); values are mean \pm S.D., $n=8$ for each group, ${ }^{* *} P<0 \cdot 01$. Histology of the metaphysis of an undecalcified section of tibia of aged PGIS $^{-1-}$ mice stained by Von Kossa staining (D) (scale bar $=0.5 \mathrm{~mm}$ ) showed an increase in the mineralized bone matrix. Counterstaining with toluidine blue and TRAP specimens (E, scale bar $=400 \mu \mathrm{m}$ and F, scale bar $=200 \mu \mathrm{m})$ showed an increase in the trabecular bone along the marrow space. An increase in TRAP-positive osteoclast cells occurred along the bone surface. 
At 5 weeks of age, lower bone mineral density (BMD) was observed in $\mathrm{PGIS}^{-1-}$ mice by soft $\mathrm{X}$-ray photographs (Fig. 2A), micro-CT (Fig. 2B), and DXA analysis (Fig. 2C). To determine the skeletal change in more detail, we performed bone analysis by using micro-CT analysis. Fractional trabecular bone volume BV/TV (\%) in $\mathrm{PGIS}^{-/-}$ mice was decreased as compared to that in the WT mice (Fig. 2D).

\section{Adult PGIS ${ }^{-1-}$ mice have increased trabecular bone mass}

The increasing bone mass phenotype was observed in PGIS $^{-/-}$mice (Fig. $3 \mathrm{~A}$ and $\mathrm{B}$ ). Corresponding to the time-dependent study by pQCT measurement, 34-week-old $\mathrm{PGIS}^{-/-}$mice showed an increase in the trabecular BV/TV as compared to PGIS ${ }^{+/-}$mice (Fig. 3C) (each group, $n=8$ ). This increase can be visualized in two-dimensional micro-CT images at the dense trabeculation in metaphyseal regions along the midshaft area. Although female mice were used in our study, these bone phenotypes were observed in both females and males (Supplementary Figure $1 \mathrm{~A}$ and B, see section on supplementary data given at the end of this article).

Based on histochemical sections of tibia examined by Von Kossa staining, the PGIS $^{-/-}$mice showed a greater mass of trabecular bone along the marrow space of the tibia distal metaphyseal area, as compared with the PGIS ${ }^{+/-}$mice. The results of Von Kossa staining indicated that the trabecular bones filling in the marrow space were well mineralized in adult PGIS $^{-1-}$ mice (Fig. 3D). Toluidine blue and TRAP staining showed an increase in the number of osteoclast-like cells along the newly formed bone surface (Fig. 3E and F). In a histomorphometric analysis of adult PGIS $^{-1-}$ mice, both bone formation and bone resorption parameters were increased (Fig. 4A-G). To determine whether the increase in trabecular bone mass was due to an acceleration in bone formation, a dynamic histomorphometric analysis was performed by using double-fluorochrome labeling at a 7-day interval with demeclocycline and calcein, which are markers of the amount of newly formed bone (Fig. 5A). The results demonstrated increases in the bone formation parameters of mineral surface per bone surface, bone formation rate, and mineral appositional rate (Fig. 5B-D). The serum osteocalcin level, which is a biochemical parameter for bone formation, was significantly increased in $\mathrm{PGIS}^{-/-}$mice (Fig. 5E). Serum CTX, which represents bone resorption activity, was also increased in PGIS ${ }^{-1-}$ mice (Fig. 5F).

\section{Bone phenotype was rescued in crossbred PGIS ${ }^{-}$tg $^{\text {tg }}$ mice}

The PGIS gene was abundantly expressed in PGIS ${ }^{\mathrm{tg} / \mathrm{tg}}$ mice. The mRNA expression in PGIS ${ }^{\text {tg }}{ }^{\mathrm{tg}}$ mice was increased $2 \cdot 5$ to 3-fold compared to that in WT mice (data not shown). $\mathrm{PGIS}^{\mathrm{tg} / \mathrm{tg}}$ mice displayed no skeletal phenotypic change. We next examined whether changes in skeletal phenotypes occurred in the offspring of overexpressed PGIS mice crossbred with PGIS-null mice. The PGIS ${ }^{-}{ }^{\text {tg }}$ mice showed the rescuing of the bone phenotype, as confirmed by micro-CT analysis (Fig. 6A). The trabecular $\mathrm{BV} / \mathrm{TV}$ value was recovered by $\sim 50 \%$ as compared to $\mathrm{PGIS}^{-/-}$mice (Fig. 6B). To confirm that the morphological changes corresponded to the biochemical aspect, we measured serum osteocalcin and CTX. Similar to the radiographic results, the serum osteocalcin level in $\mathrm{PGIS}^{-}{ }^{\text {tg }}$ mice tended to be recovered to the level in PGIS ${ }^{+/-}$mice (Fig. 6C); the serum CTX level in PGIS ${ }^{-} /^{\text {tg }}$ mice was significantly lower than that in PGIS $^{-/-}$mice and was similar to the level in PGIS $^{+/-}$mice (Fig. 6D). Notably, PGIS ${ }^{+/-} /{ }^{\text {tg }}$ mice were not different from the $\mathrm{PGIS}^{+/-}$group by micro-CT and histological analysis (Supplementary Figure 2A-C, see section on supplementary data given at the end of this article).
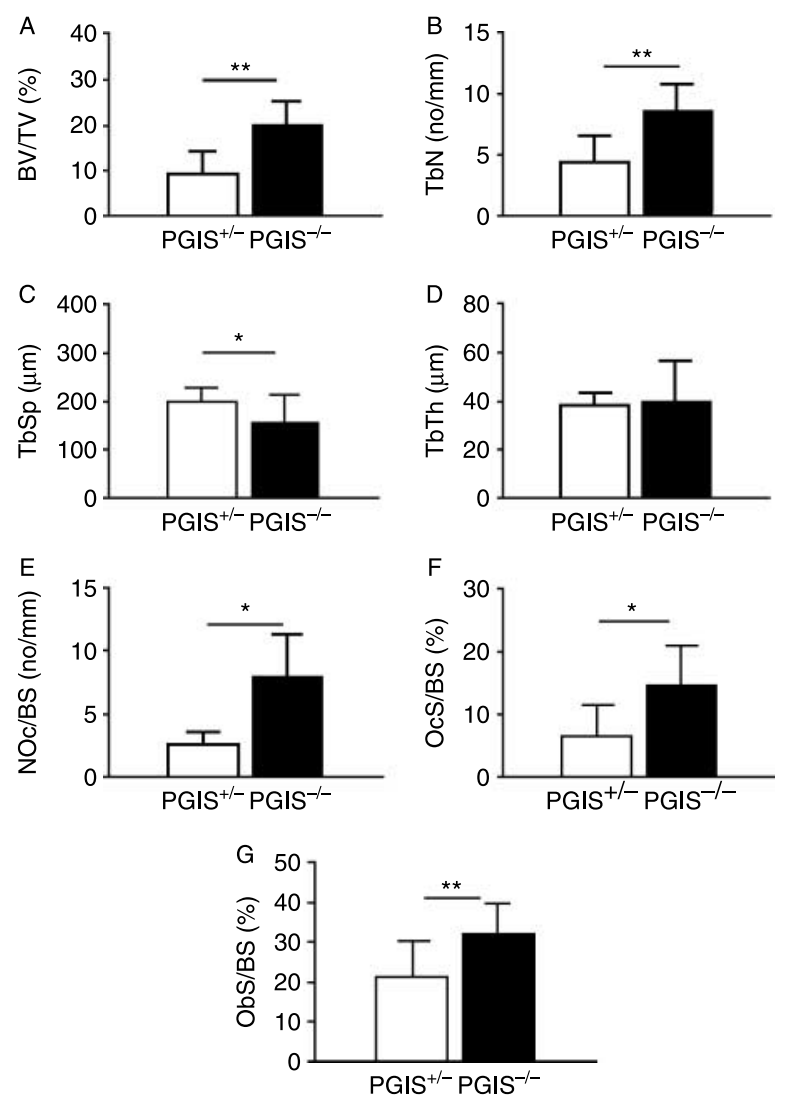

Figure 4 The increase in trabecular bone in $\mathrm{PGIS}^{-1-}$ mice was the net result of increased bone forming and bone resorption parameters. Histomorphometric analysis of undecalcified tibia metaphysis sections of adult PGIS ${ }^{-1-}$ mice was measured by KS400 analyzer. Aged $\mathrm{PGIS}^{-1-}$ mice displayed a significant increase in $\mathrm{BV} / \mathrm{TV}(\%)(\mathrm{A})$ and trabecular number $(\mathrm{TbN}, \mathrm{no} / \mathrm{mm})(\mathrm{B})$, and a decrease in trabecular separation $(\mathrm{TbSp}, \mu \mathrm{m})(\mathrm{C})$ and $\mathrm{PGIS}^{-1-}$ mice showed normal trabecular thickness (TbTh, $\mu \mathrm{m})(\mathrm{D})$. A significant increase in the osteoblast surface/bone surface (ObS/BS \%) was observed in $\mathrm{PGIS}^{-1-}$ mice (G). Osteoclast number per bone surface (NOc/BS, \%) and osteoclast surface per bone surface (OcS/BS, \%) were also increased in $\mathrm{PGIS}^{-1-}$ animals ( $\mathrm{E}$ and $\mathrm{F}$ ). Values are mean \pm s.D., $n=5, * P<0 \cdot 05, * * P<0 \cdot 01$. 


\section{Discussion}

PGs usually have a biphasic effect on bone formation, which is mediated by cAMP regulation (Raisz \& Fall 1990, Raisz 1999). The roles of endogenous PGs in skeletal growth are suggested by studies of fracture repair and heterotropic ossification, which probably involve the production of both $\mathrm{PGE}_{2}$ and $\mathrm{PGI}_{2}$ (Rawlinson et al. 1991, 2000, Raisz 1999). PGs have important effects on the skeleton, and it is strongly suggested that these effects are moderated by different receptors and specific pathways, which still remain unidentified. A large number of specific PG receptor gene-deleted animals have been cloned (Sugimoto \& Narumiya 2007). $\mathrm{PGE}_{2}$ stimulates bone formation and bone resorption via the EP4 receptor. EP4 agonist is an effective bone anabolic agent in rats (Hagino et al. 2005, Ito et al. 2006); however, the efficacy of the anabolic effect in mice is limited (Kato et al. 2007). In regards to the bone phenotype in EP4-knockout animals,
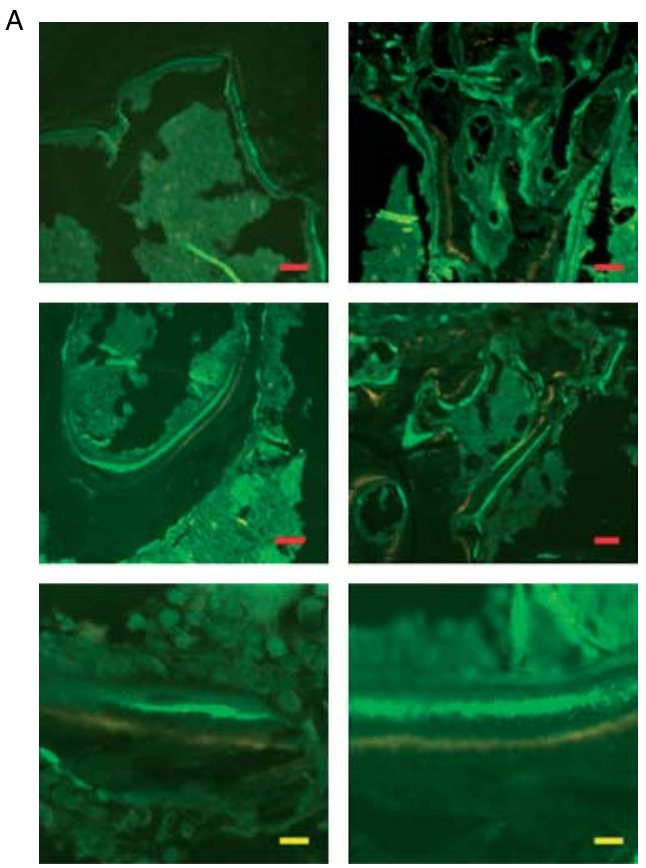

$\mathrm{PGIS}^{+/-}$

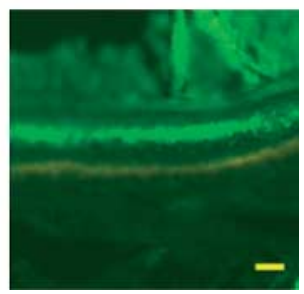

$\mathrm{PGIS}^{-/-}$
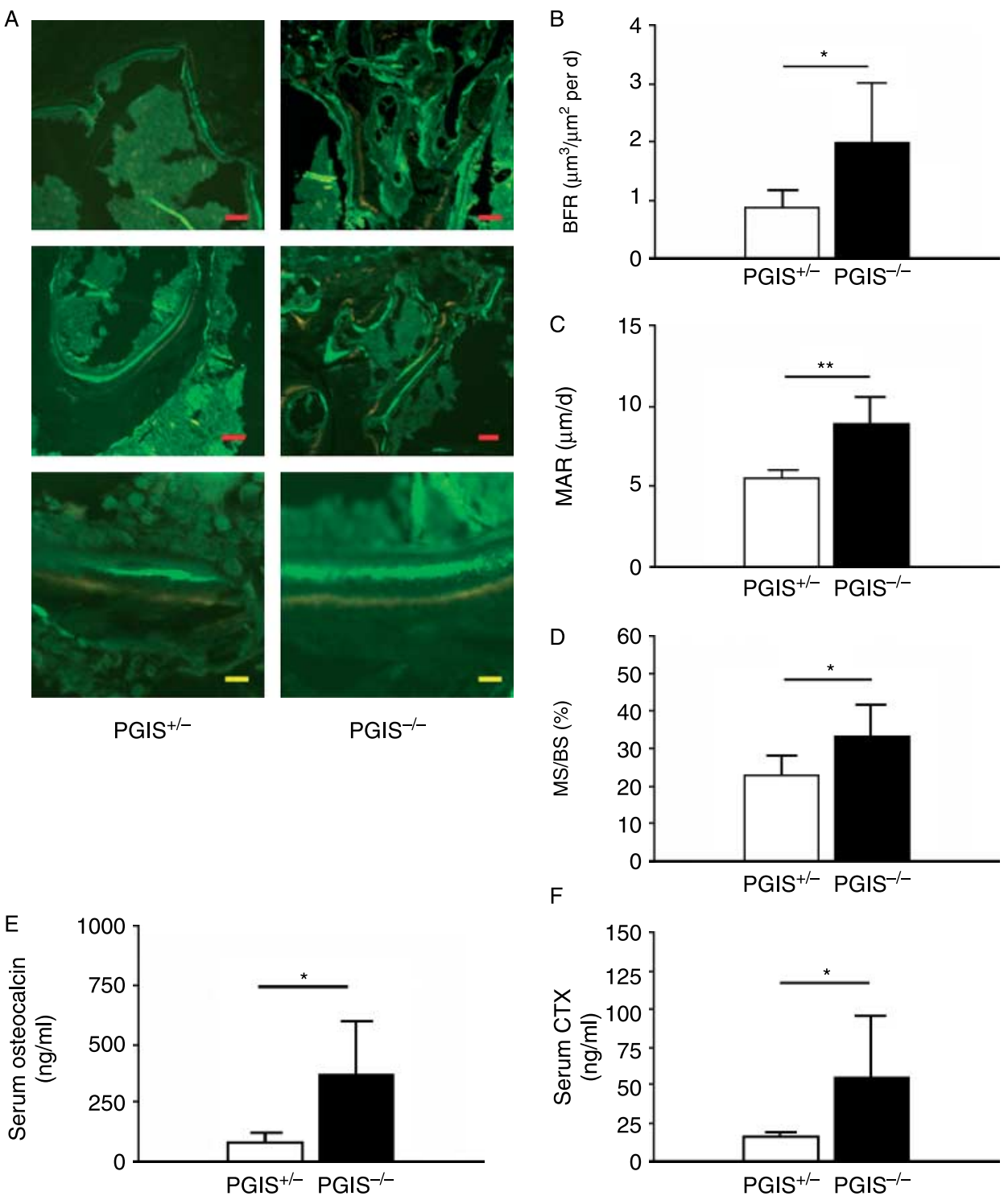

$\mathrm{F}$

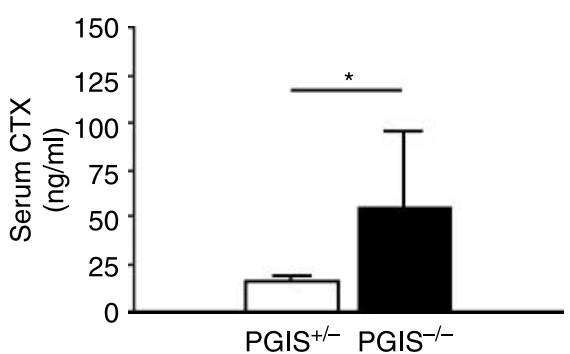

Figure 5 Adult $\mathrm{PGIS}^{-1-}$ mice have increased bone turnover activity. Dynamic histomorphometry of trabecular bone in undecalcified sections of the metaphysis of tibia was studied by double-fluorochrome labeling. Demeclocycline (yellow) and calcein (green) were injected in 7-day intervals (A) (scale bars; $\mathrm{red}=40 \mu \mathrm{m}$ and yellow $=5 \mu \mathrm{m})$. PGIS $^{-1-}$ mice displayed a significant increase in the bone formation rate per bone surface (BFR, $\mu \mathrm{m}^{3} / \mu \mathrm{m}^{2}$ per d) (B), mineral apposition rate (MAR, $\left.\mu \mathrm{m} / \mathrm{d}\right)(\mathrm{C})$, and mineral surface per bone surface (MS/BS, \%) (D); values are mean \pm s.D., 34 -week-old PGIS ${ }^{-1-}$ mice, $n=5$ for each group. Serum osteocalcin $(\mathrm{OCN})$ and CTX levels were measured by ELISA (E and F). Values are mean \pm s.D., $n=6$ for each group, $* P<0 \cdot 05, * * P<0 \cdot 01$. 

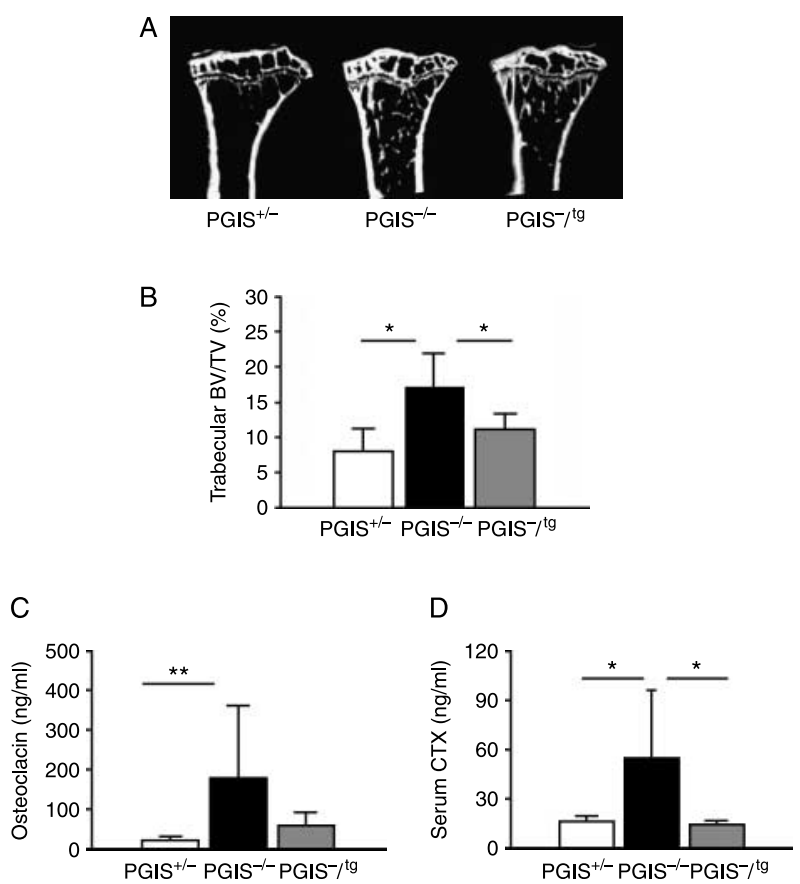

Figure 6 Enhancement of PGIS gene expression recovered the high bone mass phenomenon. PGIS ${ }^{-} / \mathrm{g}$ littermates showed a $50 \%$ recovery of the high bone mass phenotype, as determined by microCT image analysis ( $\mathrm{A}$ and $\mathrm{B}$ ) (values are mean \pm s.D., $n=8$, except PGIS ${ }^{-19}$ mice, $\left.n=6,{ }^{*} P<0 \cdot 05\right)$. Two serum bone markers, OCN (C) and CTX (D), were quantified by ELISA. Values are mean \pm s.D., $n=6, * P<0 \cdot 05, * * P<0 \cdot 01$.

mice with a global deletion of the EP4 receptor developed osteopenia and impaired fracture healing with age (Li et al. 2005), while a recent study showed that targeted deletion of the EP4 receptor showed no skeletal change in aged mice (Gao et al. 2009). Thus, the roles of $\mathrm{PGI}_{2}$ in bone metabolism may be associated with different underlying mechanisms. It has been demonstrated that the injected iloprost, a stable $\mathrm{PGI}_{2}$ analog, stimulated calvarial bone formation in postnatal rats (Tuncbilek et al. 2008). Their data may support our present observation in which at 5 weeks of age, the BMD was lower in PGIS $^{-1-}$ mice.

In the present study, we primarily observed the skeletal changes in PGIS ${ }^{-1-}$ mice by $\mathrm{pQCT}$ and micro-CT analysis. Lower bone mass was observed in 5-week-old PGIS ${ }^{-1-}$ mice and was corrected at puberty period at $6-8$ weeks old, which may have occurred from adapting process or changes in endogenous hormone levels. Unexpectedly, $\mathrm{PGIS}^{-/-}$mice showed a gradual increase in trabecular density and BV/TV values in age-dependent manner, while changes in cortical component in adult period of life were limited.

By histology and histomorphometry, we found that adult PGIS $^{-1-}$ mice displayed increases in bone formation and bone resorption parameters. This phenomenon was confirmed by measurements of serum bone markers, osteocalcin and CTX, which were significantly increased. The total net result in increased bone mass may be caused by the favoring of bone formation over bone resorption. Therefore, we performed a mineralized nodule formation assay, osteoclast formation, and pit assay with bone marrow cells derived from these mice. However, these in vitro assays did not show any differences between $\mathrm{PGIS}^{-1-}$ and PGIS $^{+/-}$mice (Supplementary Figure 3A-D, see section on supplementary data given at the end of this article). Thus, our in vitro data suggest that the lack of $\mathrm{PGI}_{2}$ does not affect the ability of bone precursor cells to differentiate.

While PGIS ${ }^{\mathrm{tg} / \mathrm{tg}}$ mice showed no distinct skeletal changes, bone mass and serum bone markers of the crossbred $\mathrm{PGIS}^{-} /^{\mathrm{tg}}$ mice were rescued back to normal, as compared with those of knockout animals. These data confirmed that the lack of $\mathrm{PGI}_{2}$ in mice caused the accelerated bone turnover and that $\mathrm{PGI}_{2}$ may play a role as a negative regulator of bone metabolism, although it is not clear how the mechanism of $\mathrm{PGI}_{2}$ is involved.

Bone is a highly vascular structure. Blood supply in bone is important for bone modulation and remodeling. $\mathrm{PGI}_{2}$ is mainly released by vascular endothelial cells. The signaling of $\mathrm{PGI}_{2}$ via its cell surface receptor, the IP receptor, is well documented in vascular biology and inflammatory responses. IP receptor serves the critical roles with the vasodilatation, mediating platelet aggregation and controlling vascular smooth muscle cell proliferation (Namba et al. 1994, Murata et al. 1997, Stitham et al. 2007). It is demonstrated that there is a communication between endothelial and bone cells, which is important for controlling vascular supply during bone growth, remodeling, and repair (Deckers et al. 2000, Clarkin et al. 2008). However, there is no report of any changes in the bone phenotype of IP receptor knockout mice. Meanwhile, $\mathrm{PGI}_{2}$ action via nuclear receptors in other physiological responses is gradually being more appreciated. $\mathrm{PGI}_{2}$ exerts its effects by interacting with a nuclear hormone receptor, the peroxisome proliferator-activated receptor (PPAR). Therefore, the response to $\mathrm{PGI}_{2}$ should be considered by both IP and PPAR in certain cell types (Namba et al. 1994, Hertz et al. 1996, Hatae et al. 2001). One of the three subtypes of PPARs, the PPAR $\delta$ uses $\mathrm{PGI}_{2}$ as an endogenous ligand to modulate specific cellular and metabolic functions (Lim et al. 1999, Gupta et al. 2000, Hatae et al. 2001). Further studies are needed to determine whether $\mathrm{PGI}_{2}$ is involved with PPAR $\delta$ signaling in bone tissues.

In conclusion, we demonstrated that the bone mass in adult $\mathrm{PGI}_{2}$-deficient mice is increased. This increase in bone mass was associated with an increase in both bone formation and bone resorption, which suggests that $\mathrm{PGI}_{2}$ deficiency accelerates high bone turnover activity with a greater increase in bone mass associated with aging. Furthermore, this imbalance was reversed in knockout animals by the insertion of PGIS overexpression. Our finding suggests that $\mathrm{PGI}_{2}$ may play a role as a regulator in maintaining normal bone mass and micro-architecture. 


\section{Supplementary data}

This is linked to the online version of the paper at http://dx.doi.org/10.1677/ JOE-09-0376.

\section{Declaration of interest}

The authors declare that there is no conflict of interest that could be perceived as prejudicing the impartiality of the research reported.

\section{Funding}

This study was supported by grants from the Ministry of Education, Culture, Sports, Science, and Technology of Japan to IM (20659306) and CY (18592060, 20592196).

\section{Acknowledgements}

We thank Drs Wantida Sriarj and Niroshani Soysa (TMD, University of Tokyo, Japan) for their technical support; and we also thank Drs Susumu Ohkawara, Yuji Arai, and Takayuki Morisaki (National Cardiovascular Center Research Institute, Osaka, Japan) for their technical support of the generation of PGIS-transgenic mice.

\section{References}

Alles N, Soysa NS, Hussain MD, Tomomatsu N, Saito H, Baron R, Morimoto N, Aoki K, Akiyoshi K \& Ohya K 2009 Polysaccharide nanogel delivery of a TNF-alpha and RANKL antagonist peptide allows systemic prevention of bone loss. European Journal of Pharmaceutical Sciences 37 83-88.

Aoki K, Saito H, Itzstein C, Ishiguro M, Shibata T, Blanque R, Mian AH, Takahashi M, Suzuki Y, Yoshimatsu M et al. 2006 A TNF receptor loop peptide mimic blocks RANK ligand-induced signaling, bone resorption, and bone loss. Journal of Clinical Investigation 116 1525-1534.

Arikawa T, Omura K \& Morita I 2004 Regulation of bone morphogenetic protein-2 expression by endogenous prostaglandin $\mathrm{E}_{2}$ in human mesenchymal stem cells. Journal of Cellular Physiology 200 400-406.

Clarkin CE, Emery RJ, Pitsillides AA \& Wheeler-Jones CP 2008 Evaluation of VEGF-mediated signaling in primary human cells reveals a paracrine action for VEGF in osteoblast-mediated crosstalk to endothelial cells. Journal of Cellular Physiology 214 537-544.

Deckers MM, Karperien M, van der Bent C, Yamashita T, Papapoulos SE \& Lowik CW 2000 Expression of vascular endothelial growth factors and their receptors during osteoblast differentiation. Endocrinology 141 1667-1674.

Gao Q, Zhan P, Alander CB, Kream BE, Hao C, Breyer MD, Pilbeam CC \& Raisz LG 2009 Effects of global or targeted deletion of the EP4 receptor on the response of osteoblasts to prostaglandin in vitro and on bone histomorphometry in aged mice. Bone 45 98-103.

Garnero P, Ferreras M, Karsdal MA, Nicamhlaoibh R, Risteli J, Borel O, Qvist P, Delmas PD, Foged NT \& Delaisse JM 2003 The type I collagen fragments ICTP and CTX reveal distinct enzymatic pathways of bone collagen degradation. Journal of Bone and Mineral Research 18 859-867.

Gupta RA, Tan J, Krause WF, Geraci MW, Willson TM, Dey SK \& DuBois RN 2000 Prostacyclin-mediated activation of peroxisome proliferator-activated receptor delta in colorectal cancer. PNAS 97 $13275-13280$.

Hagino H, Kuraoka M, Kameyama Y, Okano T \& Teshima R 2005 Effect of a selective agonist for prostaglandin E receptor subtype EP4 (ONO-4819) on the cortical bone response to mechanical loading. Bone 36 444-453.

Harada S \& Rodan GA 2003 Control of osteoblast function and regulation of bone mass. Nature 423 349-355.
Hatae T, Wada M, Yokoyama C, Shimonishi M \& Tanabe T 2001 Prostacyclin-dependent apoptosis mediated by PPAR delta. Journal of Biological Chemistry 276 46260-46267.

Hertz R, Berman I, Keppler D \& Bar-Tana J 1996 Activation of gene transcription by prostacyclin analogues is mediated by the peroxisomeproliferators-activated receptor (PPAR). European Journal of Biochemistry 235 242-247.

Hussain Mian A, Saito H, Alles N, Shimokawa H, Aoki K \& Ohya K 2008 Lipopolysaccharide-induced bone resorption is increased in TNF type 2 receptor-deficient mice in vivo. Journal of Bone and Mineral Metabolism 26 469-477.

Ito M, Nakayama K, Konaka A, Sakata K, Ikeda K \& Maruyama T 2006 Effects of a prostaglandin EP4 agonist, ONO-4819, and risedronate on trabecular microstructure and bone strength in mature ovariectomized rats. Bone 39 453-459.

Kamei D, Yamakawa K, Takegoshi Y, Mikami-Nakanishi M, Nakatani Y, Oh-Ishi S, Yasui H, Azuma Y, Hirasawa N, Ohuchi K et al. 2004 Reduced pain hypersensitivity and inflammation in mice lacking microsomal prostaglandin e synthase-1. Journal of Biological Chemistry 279 33684-33695

Kato N, Kitahara K, Rittling SR, Nakashima K, Denhardt DT, Kurosawa H, Ezura Y \& Noda M 2007 Osteopontin deficiency enhances anabolic action of EP4 agonist at a sub-optimal dose in bone. Journal of Endocrinology 193 $171-182$.

Li X, Okada Y, Pilbeam CC, Lorenzo JA, Kennedy CR, Breyer RM \& Raisz LG 2000 Knockout of the murine prostaglandin EP2 receptor impairs osteoclastogenesis in vitro. Endocrinology 141 2054-2061.

Li M, Healy DR, Li Y, Simmons HA, Crawford DT, Ke HZ, Pan LC, Brown TA \& Thompson DD 2005 Osteopenia and impaired fracture healing in aged EP4 receptor knockout mice. Bone 37 46-54.

Lim H, Gupta RA, Ma WG, Paria BC, Moller DE, Morrow JD, DuBois RN, Trzaskos JM \& Dey SK 1999 Cyclo-oxygenase-2-derived prostacyclin mediates embryo implantation in the mouse via PPARdelta. Genes and Development 13 1561-1574.

Miyaura C, Inada M, Suzawa T, Sugimoto Y, Ushikubi F, Ichikawa A, Narumiya S \& Suda T 2000 Impaired bone resorption to prostaglandin $E_{2}$ in prostaglandin E receptor EP4-knockout mice. Journal of Biological Chemistry 275 19819-19823.

Murata T, Ushikubi F, Matsuoka T, Hirata M, Yamasaki A, Sugimoto Y, Ichikawa A, Aze Y, Tanaka T, Yoshida N et al. 1997 Altered pain perception and inflammatory response in mice lacking prostacyclin receptor. Nature 388 678-682.

Naik AA, Xie C, Zuscik MJ, Kingsley P, Schwarz EM, Awad H, Guldberg R, Drissi H, Puzas JE, Boyce B et al. 2009 Reduced COX-2 expression in aged mice is associated with impaired fracture healing. Journal of Bone and Mineral Research 24 251-264.

Namba T, Oida H, Sugimoto Y, Kakizuka A, Negishi M, Ichikawa A \& Narumiya S 1994 cDNA cloning of a mouse prostacyclin receptor. Multiple signaling pathways and expression in thymic medulla. Journal of Biological Chemistry 269 9986-9992.

Parfitt AM, Drezner MK, Glorieux FH, Kanis JA, Malluche H, Meunier PJ, Ott SM \& Recker RR 1987 Bone histomorphometry: standardization of nomenclature, symbols, and units. Report of the ASBMR Histomorphometry Nomenclature Committee. Journal of Bone and Mineral Research 2 595-610.

Raisz LG 1995 Physiologic and pathologic roles of prostaglandins and other eicosanoids in bone metabolism. Journal of Nutrition 125 2024S-2027S.

Raisz LG 1999 Prostaglandins and bone: physiology and pathophysiology. Osteoarthritis and Cartilage 7 419-421.

Raisz LG \& Fall PM 1990 Biphasic effects of prostaglandin $\mathrm{E}_{2}$ on bone formation in cultured fetal rat calvariae: interaction with cortisol. Endocrinology 126 1654-1659.

Rawlinson SC, el-Haj AJ, Minter SL, Tavares IA, Bennett A \& Lanyon LE 1991 Loading-related increases in prostaglandin production in cores of adult canine cancellous bone in vitro: a role for prostacyclin in adaptive bone remodeling? Journal of Bone and Mineral Research 6 1345-1351. 
Rawlinson SC, Wheeler-Jones CP \& Lanyon LE 2000 Arachidonic acid for loading induced prostacyclin and prostaglandin $\mathrm{E}(2)$ release from osteoblasts and osteocytes is derived from the activities of different forms of phospholipase A(2). Bone 27 241-247.

Saito H, Kojima T, Takahashi M, Horne WC, Baron R, Amagasa T, Ohya K \& Aoki K 2007 A tumor necrosis factor receptor loop peptide mimic inhibits bone destruction to the same extent as anti-tumor necrosis factor monoclonal antibody in murine collagen-induced arthritis. Arthritis and Rheumatism 56 1164-1174.

Simmons DL, Botting RM \& Hla T 2004 Cyclooxygenase isozymes: the biology of prostaglandin synthesis and inhibition. Pharmacological Reviews $\mathbf{5 6}$ 387-437.

Stitham J, Arehart EJ, Gleim SR, Douville KL \& Hwa J 2007 Human prostacyclin receptor structure and function from naturally-occurring and synthetic mutations. Prostaglandins \& Other Lipid Mediators 82 95-108.

Sugimoto Y \& Narumiya S 2007 Prostaglandin E receptors. Journal of Biological Chemistry 282 11613-11617.

Tomomatsu N, Aoki K, Alles N, Soysa NS, Hussain A, Nakachi H, Kita S, Shimokawa H, Ohya K \& Amagasa T 2009 LPS-induced inhibition of osteogenesis is TNF-alpha dependent in a murine tooth extraction model. Journal of Bone and Mineral Research 24 1770-1781.

Tuncbilek G, Korkusuz P \& Ozgur F 2008 Effects of iloprost on calvarial sutures. Journal of Craniofacial Surgery 19 1472-1480.
Uematsu S, Matsumoto M, Takeda K \& Akira S 2002 Lipopolysaccharidedependent prostaglandin $\mathrm{E}(2)$ production is regulated by the glutathionedependent prostaglandin $\mathrm{E}(2)$ synthase gene induced by the Toll-like receptor 4/MyD88/NF-IL6 pathway. Journal of Immunology 168 5811-5816.

Yokoyama C, Yabuki T, Shimonishi M, Wada M, Hatae T, Ohkawara S, Takeda J, Kinoshita T, Okabe M \& Tanabe T 2002 Prostacyclin-deficient mice develop ischemic renal disorders, including nephrosclerosis and renal infarction. Circulation 106 2397-2403.

Yoshida K, Oida H, Kobayashi T, Maruyama T, Tanaka M, Katayama T, Yamaguchi K, Segi E, Tsuboyama T, Matsushita M et al. 2002 Stimulation of bone formation and prevention of bone loss by prostaglandin E EP4 receptor activation. PNAS 99 4580-4585.

Zhang X, Schwarz EM, Young DA, Puzas JE, Rosier RN \& O’Keefe RJ 2002 Cyclooxygenase- 2 regulates mesenchymal cell differentiation into the osteoblast lineage and is critically involved in bone repair. Journal of Clinical Investigation 109 1405-1415.

Received in final form 3 November 2009

Accepted 10 November 2009

Made available online as an Accepted Preprint

10 November 2009 